\title{
Spontaneous Reduction of a Closed Depressed Skull Fracture in a Child: Case Presentation
}

\author{
Alp Özgün Börcek* and Özgür Öcal \\ Gazi University Faculty of Medicine Division of Pediatric Neurosurgery, Turkey
}

Submission: April 14, 2018; Published: August 24, 2018

*Corresponding author: Alp Özgün Börcek, Gazi University Faculty of Medicine Division of Pediatric Neurosurgery, Ankara, Turkey, Email:

alpborcek@gmail.com

\begin{abstract}
Depressed skull fractures account $25 \%$ of head trauma of childhood head trauma. They can be classified as open or closed and most of the open fractures require surgical intervention and closed ones could be followed-up when they fulfill indications such as absence of neurological deficit. Literature has examples of spontaneous healing of depressed fractures that did not undergo surgery. This report aims to present a severe depressed skull fracture that was managed conservatively.
\end{abstract}

Keywords: Depressed; Skull; Fractures; Head trauma; Surgery; Remodeling

\section{Case Report}

A 12-year-old male was admitted due to head trauma after a fall from $5 \mathrm{~m}$ height. He had no neuro deficits. His computerized tomography (BT) revealed a closed depressed skull fracture at the left parieto-occipital region. His magnetic resonance imaging revealed compromise in superior sagittal sinus. His family was offered a reduction surgery; however, parents refused any surgical intervention. His follow up period was uneventful, and he was discharged at the 7th day of trauma. His control imaging at the 3 rd year of the event reveled significant remodeling of the calvaria (Figure 1).

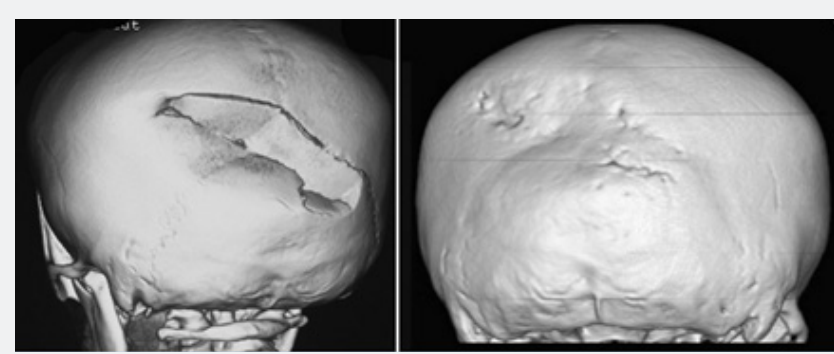

Figure 1: Remodeling of the calvaria.

\section{Discussion}

Children have flexible bone structures due to lower mineralization and flexible suture lines. Additionally, they have higher osteogenic potential when compared to adults due to extensive vascularity. These properties of young patients pose a chance for spontaneous healing of depressed skull fractures. Hung et al have published a case series of depressed skull fractures that were successfully managed with conservative treatment.

\section{Conclusion}

Patients presenting with depressed skull fractures that do not have significant intracranial pathologies such as hematomas or brain damage and fully awake, neurologically intact patients could be closely followed up after a head trauma without surgery. However, one should remember that not performing surgery could bare its own risks such as cosmetic deformity or epilepsy in the long term. 
Your next submission with Juniper Publishers will reach you the below assets

- Quality Editorial service

- Swift Peer Review

- Reprints availability

- E-prints Service

- Manuscript Podcast for convenient understanding

- Global attainment for your research

- Manuscript accessibility in different formats

( Pdf, E-pub, Full Text, Audio)

- Unceasing customer service

Track the below URL for one-step submission https://juniperpublishers.com/online-submission.php 